\title{
Chronic Arsenicosis with Basal Cell Carcinoma of Scalp: A Rare Co-incidence
}

Dipankar Pal ${ }^{\star}$, Manoj Kumar Gupta, Dushyant Kumar Lahre, Manab Kumar Ghosh and Shekhar Pal

School of Tropical Medicine, Kolkata, India

*Corresponding author: Dipankar Pal, RMO cum Clinical Tutor, Department of Tropical Medicine, School of Tropical Medicine, Kolkata, India, Tel: +91-9432113713; Email: dipankarpal.2009@gmail.com

Received date: July 6, 2015, Accepted date: July 8, 2015, Published date: July 11, 2015

Copyright: (C) 2015 Dipankar P et al. This is an open-access article distributed under the terms of the Creative Commons Attribution License, which permits unrestricted use, distribution, and reproduction in any medium, provided the original author and source are credited.

\section{Clinical Image}

Arsenic is a natural semi-metallic chemical that is found all over the world in groundwater. The WHO cut-off value for arsenic in drinking water is $0.01 \mathrm{mg} / \mathrm{L}$ [1]. Chronic arsenicosis is caused by long term exposure to arsenic compounds via ingestion or inhalation. Basal cell carcinoma is the commonest skin malignancy accounting for upto $80 \%$ of all cancers arising from epidermis [2]. Its main modality of treatment is surgery and is generally curative.

A 65 years old nonsmoker, non-diabetic, male farmer by occupation presented with pigmentation of generalised skin surface, palms and soles.

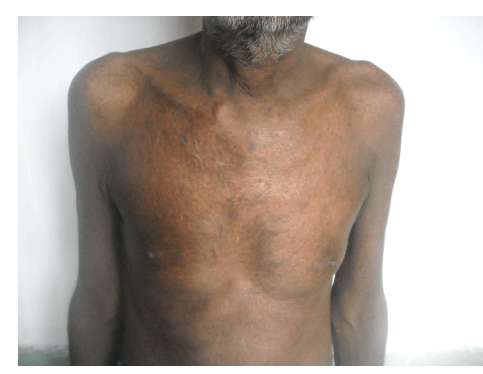

Figure 1: Skin changes of chest and abdomen.

He noticed areas of hyper and hypo pigmentation around the trunk ten years back which gradually extended to involve generalized skin surface (Figure 1), palms (Figure 2) and soles along with the development of warty lesions in both feet (Figure 3).

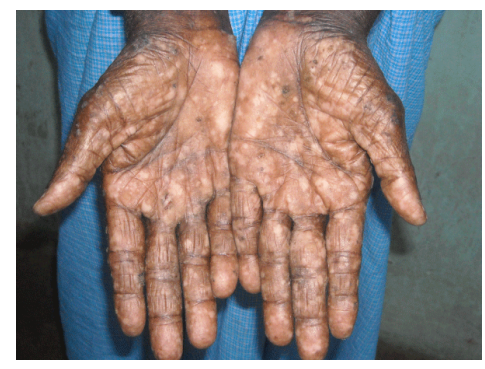

Figure 2: Hyper and hypopigmentation of both palms.

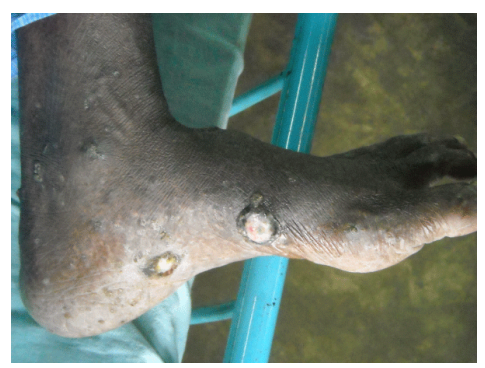

Figure 3: Hyperpigmentation and warty lesions of left foot.

He had no history of cough, chest tightness, breathing difficulty and bladder, bowel dysfunction. Arsenic estimation was done from his hair and nail showing high values.

Three and a half years before he developed a small nodule on the scalp, which gradually enlarged in size to become a sharply demarcated non healing ulcer. It has a size of $5 \times 6 \mathrm{~cm}$ with a clear base during presentation (Figure 4).

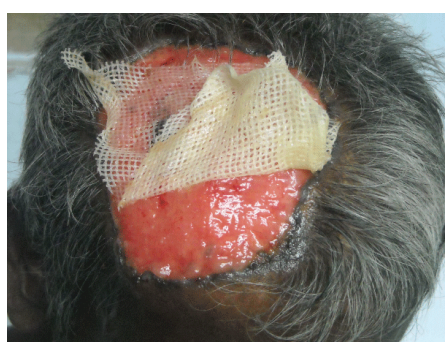

Figure 4:Large ulcer over scalp diagnosed as basal cell carcinoma on histopathology.

Histopathology from the margin showed features consistent with basal cell carcinoma.

\section{Conclusion}

Chronic arsenicosis is a health hazard in tropical countries due to drinking of ground water containing high level of arsenic. Long-term arsenic ingestion can lead to certain cancers e.g. bladder, kidney, liver, lung and skin. But co-incidence of basal cell carcinoma and chronic arsenicosis is rare in the literature.

Conflicts of interest: None declared 
Citation: Dipankar P, Manoj KG, Dushyant KL, Manab KG, Shekhar P (2015) Chronic Arsenicosis with Basal Cell Carcinoma of Scalp: A Rare Co-incidence. Trop Med Surg 3: I102. doi:10.4172/2329-9088.1000I102

Page 2 of 2

\section{References}

1. Diagnosis and treatment of chronic arsenic poisoning by Dr. D.N. Guha Mazumder Downloaded from: www.who.int/ water_sanitation_health/dwq/arsenicun4.pdf
2. Rubin AI, Chen EH, Ratner D (2005) Basal-cell carcinoma. N Engl J Med 353: 2262-2269. 